\title{
Employer Behavior in Certification Elections and First-Contract Campaigns: Implications for Labor Law Reform
}

\author{
Kate L. Bronfenbrenner
}

Organizing is an extremely risky and arduous venture for American workers. As the experience of the last twenty years has shown, a combination of unfettered employer antiunion behavior and weak and poorly enforced labor law make for an "unlevel playing field" stacked against unorganized workers and unions. Using survey data from private-sector certification election and first-contract campaigns, this chapter will first examine the impact of NLRB practices and legal and illegal employer behavior on union election and firstcontract outcomes. It will then evaluate how labor law reform would reduce the ability of employers to undermine workers' efforts to organize and win first agreements.

Although there has been a great deal of research on the relationship between employers' unfair labor practices and election outcomes, there has been very little research on the broad range of legal and illegal tactics used by employers during the NLRB election process, regardless of whether unfair labor practices were actually filed. Even fewer studies have controlled for the influence of bargaining unit demographics, organizer background, and union tactics during organizing campaigns. In addition, only a handful of studies have examined employer and union behavior during first-contract campaigns, even though a union election victory is at best Pyrrhic without a firstcontract victory. This study can therefore provide new and important insights into the impact of NLRB practices and employer behavior on election and first-contract outcomes as well as the need for and ramifications of significant labor law reform. ${ }^{1}$

1. My dissertation (1993) provides an in-depth review of the industrial relations research literature relating to organizing and first-contract campaigns. 


\section{Hypotbeses}

This study will test the hypotheses that NLRB practices and legal and illegal employer behavior play a significant role in determining union success in elections and first agreements and that specific labor law reform will substantially diminish the negative impact of these factors. Variables relevant to labor law reform during the organizing drive include the number of days between petition and election, the percentage of cards signed, unit challenges, discharges for union activity, employer promises of improvements in wages or benefits, wage increases, captive audience meetings, company mailings, and unfair labor practice charges and complaints.

Variables to be examined during the first-contract campaign include election objections; postelection discharges, threats, and promises; unilateral changes in wages and benefits; staffing changes; captive audience meetings; full or partial plant shutdowns; the use of surface bargaining and other hard bargaining strategies; decertification drives; and attempts to undermine the committee and divide union membership.

The proposed labor law reforms include recognition after a majority card check; a consistent community of interest standard for unit determination; more vigorous and speedier enforcement of NLRB penalties for unfair labor practices, including discharges, threats, promises, unilateral changes, and refusal to bargain; financial and injunctive relief for more egregious violations, especially $8(a)(3)$ and $8(a)(5)$ charges; greater access for union organizers to the company premises; and stronger restrictions and penalties for employers that shut down operations or contract out work to avoid unionization.

\section{Data and Metbodology}

This chapter relies on data collected for my dissertation, entitled "Seeds of Resurgence: Successful Union Strategies for Winning Certification Elections and First Contracts in the 1980's and Beyond" (1993). Although the primary focus of that research was to determine which union strategies had the most positive impact on union certification election and first-contract outcomes, the study also included a wealth of data on employer behavior and other unit and election background variables.

This study is based on a random sample of 261 NLRB certification elections that took place between July 1986 and June 1987. Only singleunion elections involving AFL-CIO affiliates in units of fifty or more eligible voters were included. The data were collected in cooperation with the AFL$\mathrm{CIO}$, building on and refining its earlier survey of 189 organizing campaigns (AFL-CIO 1989). The 261 elections in the final sample represent approximately a third of the total elections in units with more than fifty during that 
period and are representative across unions, industries, regions, and types of bargaining units. ${ }^{2}$

Lead organizers for each of the campaigns completed a lengthy survey regarding their backgrounds, bargaining unit demographics, company characteristics and tactics, and union tactics. In addition, for 100 out of the 119 bargaining units in which the union won the election or won a second election between the election and the time the survey was completed, follow-up interviews were conducted with the union representative in charge of contract negotiations. The second survey included questions regarding the bargaining climate, the negotiation process, the negotiator's background, employer and union characteristics and tactics, as well as the outcome of bargaining.

Descriptive statistics were calculated for each of the NLRB practices and employer behavior variables to provide an in-depth portrait of the extent and nature of employer behavior and NLRB practices during organizing and firstcontract campaigns. In addition, multivariate regression and logit analyses were used to determine whether specific variables had a statistically significant impact on certification and/or first-contract outcome when controlling for the influence of other election background, election environment, company characteristics, bargaining unit demographics, management tactic, union tactic, and union control variables. ${ }^{3}$

\section{Results of the Certification Election Study}

The results of the certification election study document both the pervasive nature of aggressive employer antiunion behavior during organizing campaigns and the negative impact that current NLRB practices and legal and illegal employer behavior have on certification election outcome.

2. There were a total of 961 single-union elections involving AFL-CIO affliates in units with more than fifty voters during the period examined. The restriction on bargaining unit size focuses the study on significant union campaigns rather than on those involving just a handful of workers. In 1986, union win rates averaged 51 percent in the 2,635 units with fewer than fifty eligible voters, compared with 37 percent in the 1,236 units with fifty or more eligible voters. Because the failure of unions to win larger units is such a critical element of the labor law teform debate, and because it is more difficult to measure the impact of bargaining unit demographic and union and employer tactic variables in smaller bargaining units, limiting the sample to larger units helps focus the study on those units in which union and employer behavior have the most meaningful impact on election outcome.

3. For the organizing study, three different equations were used. The first two equations, with a dependent variable of percent union vote, used ordinary least squares (OLS) and weighted least squares (WLS) as the method of analysis; the third equation, with the dependent variable of election win or loss, used logit as the statistical method of analysis. For the purpose of this paper, the results for the OLS and logit equations are included. The first-contract study utilized just one equation, with the dependent variable of contract win or loss and logit as the method of analysis. A more in-depth explanation of the methodology utilized in both studies can be found in my dissertation (1993). 


\section{Impact of NLRB Practices on Election Outcome}

One of the primary concerns of the labor movement is the lengthy delays between the time a petition is filed and the election is held. In this study, delays ranged from less than a month to more than two years. As we can see from table 5.1, the win rate was much higher in units in which the election was held less than two months after the petition was filed ( 53 percent) than when the election was held two to six months after the petition was filed (41 percent). For the 6 percent of the campaigns in which delays were longer than six months, the win rate increased to 60 percent.

This by no means tells us that delays benefit unions. Clearly, delays give employers a longer time period in which to campaign aggressively against the union. Many of the unions that were unable to maintain bargaining unit support after lengthy delays may have withdrawn from the campaign rather than going ahead with an election they were certain to lose. Because only campaigns that actually went to an election were included in the sample, the negative impact of delays is therefore underestimated.

The high percentage of campaigns in which there was a majority or near majority of signed cards makes it clear that if the election were held on the same day the petition was filed, or if certification could be achieved by card checks rather than elections, union win rates would nearly double. Although unions are required to collect signatures from only 30 percent of the unit to have an election, in more than 73 percent of the campaigns studied, unions signed up a majority of the unit on cards before the election. In addition, in more than 84 percent of the campaigns, the unions got within 5 percent of a majority and might have been able to get a majority signed up if they had known card signing would result in instant certification. ${ }^{4}$

Unions did especially poorly in elections in which the original unit the union petitioned for was changed by stipulation or by order of the board or courts. Unions won only 23 percent of the elections in those cases in which the unit was changed, compared with a 47 percent win rate in units that remained unchanged throughout the unit determination process. When the influence of other election campaign variables are controlled for, the results further suggest that the percentage union vote declines by 4 percent and the probability

4. The results for the card check variable are further substantiated by a recent study I conducted with Tom Juravich (1994), which established the first-ever national database of public-sector union certification campaigns. Several states, including New York, Washington, and South Dakota, permit certification through card check for public-sector workers as long as employers do not contest the unit and/or demand an election. Juravich and I found thar in those states permitting card checks, the average percentage of the eligible voters who signed cards was 85 percent, well beyond the majority plus one required for certification. This also counteracts claims that if card signing led to certification rather than to an election, the percentage of cards signed would drop dramatically. 


\begin{tabular}{|c|c|c|c|c|}
\hline Independent variable & $\begin{array}{c}\text { Mean or percent } \\
\text { of sample }\end{array}$ & $\begin{array}{c}\text { Percent of } \\
\text { union-win rate } \\
\text { (rate when not present) }\end{array}$ & $\begin{array}{c}\text { Predicted impact on } \\
\text { percent union vote }\end{array}$ & $\begin{array}{c}\text { Predicted impact on } \\
\text { probability of union win }\end{array}$ \\
\hline Number of days from petition election & 79 days average & N.A. & - & - \\
\hline 60 days or less & 53 & 50 & - & - \\
\hline $60-180$ days & 41 & 31 & - & - \\
\hline 180 days or more & 6 & 60 & - & - \\
\hline Percent signed cards & $60 \%$ average & N.A. & $3 \%$ for $10 \%$ increase in cards & $5 \%$ for $10 \%$ increase in cards \\
\hline More than $50 \%$ & 73 & $51(20)$ & - & - \\
\hline Precampaign participation plan & 7 & $22(44)$ & $-6 \%$ with plan & $-22 \%$ with plan \\
\hline Unit changed after perition & 22 & $22(47)$ & $-4 \%$ if unit different & $-15 \%$ if unit different \\
\hline Management consultant used & 71 & $40(50)$ & $-11 \%$ if consultant used & $-3 \%$ if consultant used \\
\hline Discharges not reinstated & 18 & 37 (44) & $-1 \%$ if not reinstated & $-8 \%$ if not reinstated \\
\hline All units with discharges & 30 & $51(40)$ & - & - \\
\hline Company gave wage increase & 30 & $32(47)$ & $-7 \%$ if wage increase & $-9 \%$ if wage increase \\
\hline Company made promises & 56 & $34(54)$ & $-3 \%$ if promises made & $-13 \%$ if promises made \\
\hline Antiunion committee used & 42 & $37(46)$ & $-6 \%$ if anti-union committee & $-1 \%$ if anti-union committee \\
\hline Number of captive audience meetings & 5.5 meetings average & N.A. & $-.2 \%$ for each additional meeting & $-1 \%$ for each additional meeting \\
\hline No captive audience meetings & 18 & 42 & - & - \\
\hline 20 or more meetings & 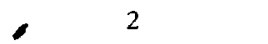 & 18 & - & - \\
\hline Number of company letters & 4.5 letters average & N.A. & $-.5 \%$ for each additional letter & $-1 \%$ for each additional letter \\
\hline No company letters & 21 & 45 & - & - \\
\hline More than 5 letters & 30 & 37 & - & - \\
\hline Supervisor campaigned one-on-one & 79 & $41(43)$ & - & - \\
\hline ULP charges filed & 36 & 41 (43) & - & - \\
\hline Complaints won on charges filed & 53 & $53(40)$ & - & - \\
\hline Total for all 261 cases in sample & 100 & 43 & - & - \\
\hline
\end{tabular}

Note: Including predicted impact on percent unit vote and probability of a union win for all variables included in the regression and logit equations when controlling for the influence of election environment, company and unit characteristic, and union tactic and characteristic variables. Statistically significant results are in bold for all variables that were included in those equations. 
of the union winning an election declines by as much as 15 percent when the unit is changed after the petition is filed.

Unit changes appear to have had an especially negative impact in those campaigns in which the final unit included other unorganized worksites or divisions of the corporation. Several unions in the sample lost elections, despite winning more than 70 percent of the votes in the unit they originally petitioned for, because the board added another branch of the company, doubling the number of eligible voters just weeks before the election.

The use of participation schemes, team concept, and other employee involvement programs appears to have been an especially effective union-avoidance tactic for the 7 percent of the employers in the sample that had these programs in place before the election campaign began. Although the number of cases is too small to come to any definitive conclusions, win rates were 22 percent lower in these units, and the predicted negative impact on the percentage union vote and the probability of the union winning the election were 6 and 22 percent respectively.

\section{Management Tactics during Campaigns}

More than 75 percent of the employers in the sample engaged in active antiunion tactics, including some combination of discharges for union activity; captive audience meetings; supervisor one-on-ones; wage increases; promises of improvements in wages, benefits, or working conditions; antiunion committees; and letters. With the exception of the consultant and discharge variables, all of the management tactics variables exhibited a statistically significant negative impact on either percentage union vote or election outcome when the influence of other election campaign variables were controlled for.

Seventy-one percent of the employers in the sample utilized a management consultant during their election campaigns. The win rate associated with campaigns in which the employer used an outside consultant was 40 percent, versus 50 percent in campaigns in which no outside consultant was used.

The failure of the consultant variable to have a strong negative effect may be due to a growing trend among larger corporations to use lawyers on retainer or to hire their own in-house labor relations specialists. These lawyers and in-house consultants play the same role as management consultants but do not have to register under the Labor-Management Reporting and Disclosure Act (LMRDA). Fifteen percent of the campaigns used outside lawyers on retainer, many of whom acted as management consultants in practice though not in name, bringing to 86 percent the number of units that used some kind of outsiders during the management campaign. Several employers in the sample, especially national chains, such as Beverly Enterprises, Inc., had in- 
house labor relations specialists who ran by-the-book aggressive antiunion campaigns, complete with numerous unfair labor practices. These in-house human resource specialists may have received the same training and may have served the same purpose as the outside management consultants, but they were not counted in calculating the impact of the management consultant variable.

The lead organizers surveyed claimed that employers discharged workers for union activity in 30 percent of the campaigns. Although unions filed $8($ a) (3) charges in 87 percent of the campaigns in which workers were fired for union activity, complaints were issued in only 43 percent of the campaigns with discharges. Discharged workers were reinstated before the election in only 40 percent of these campaigns. In five campaigns, the NLRB ordered reinstatement after the election had taken place, too late for those workers to vote and too late to affect the election outcome positively. This meant that workers were reinstated before the election in only 34 percent of the campaigns in which there were discharges for union activity. Although win rates averaged 10 percent higher in units in which there were discharges than in units without any discharges for union activity, win rates were only 37 percent in units in which the union was unable to win reinstatement for any discharged workers before the election took place.

These mixed results for the discharge variables should not be interpreted as evidence that discharges for union activity do not have a devastating impact on workers' willingness and ability to organize. It is very likely that employers resort to discharges for union activity only during those campaigns in which the union has a good chance of winning the election. Discharges backfired for employers only in the small number of cases in which the union was able to win reinstatement for discharged employees before the election, demonstrating union power and undermining the employers' ability to intimidate workers from engaging in union activity. This contrasts sharply with the majority of elections, in which unions were unable to win reinstatement for discharged workers before the election.

The negative impact of these firings is underestimated in studies of NLRB election campaigns insofar as they do now include the large number of campaigns that never make it to an election because the employer discharged workers early in the union campaign. These include campaigns in which workers are fired after the initial union contact or the first union meeting, effectively quashing the campaign before it even gets off the ground. These also include campaigns in which, despite initial majority support, the union is forced to withdraw from the election after the employer fires some or all of the rank-and-file organizing committee, undercutting the union's ability to organize inside the workplace and intimidating workers from continuing their support for the union. 
Employers granted wage increases in 30 percent of the campaigns and made promises of improvements in wages, hours, and working conditions in 56 percent, even though both of these actions can be considered violations of Section $8(a)(1)$ of the NLRA. In addition, employers established antiunion committees in 42 percent of the campaigns. The win rates associated with these employer behavior variables were 9 to 20 percent lower than in units in which these tactics were not used. The results further suggest that the percentage union vote would decline by 15 percent in units in which the company granted wage increases, by 3 percent in units in which the company made promises, and by 20 percent in units in which management utilized an antiunion committee. Similarly, we can predict that the probability of the union winning the election would decline by 9 percent in units in which the company gave wage increases and by 13 percent in units in which the company made promises during the election campaign.

Under the "free speech" provisions of the NLRA, employers have virtually unlimited opportunities to communicate aggressively with their employees during union campaigns, at the same time as union access is tightly circumscribed if not totally restricted. Under current labor law these employer communications can and often do include distortion, misinformation, threats, and intimidation, with very little chance of censure or penalty by the board or courts. The pervasiveness and intensity of employer communications with the bargaining unit are measured in this study by both the number of captive audience meetings held and the number of company letters sent. Union win rates declined dramatically as the number of meetings and letters increased, from more than 40 percent for campaigns in which no captive audience meetings were held or letters sent, down to 18 percent when the employer held twenty or more captive audience meetings and 37 percent when the company sent more than five letters during the campaign. The results further suggest that for every additional letter that the company mails out, the percentage of votes cast for the union declines by 2.5 percent and the probability of the union winning the election declines by 1 percent. Similarly, for every additional captive audience meeting, the proportion of union votes declines by .2 percent and the probability of the union winning the election declines by 1 percent.

The primary issues focused on by employers in these forums were strikes, dues and fines, and plant closings. According to the organizers surveyed, these messages often included blatant or veiled threats and repeated distortions or misinformation about the union. Thus, in the atmosphere created by captive audience meetings, in which the union has no access and little influence, the coercive nature of the antiunion message can be extremely damaging to the union campaign. 


\section{ULPs during the Campaign}

Unions filed unfair labor practice (ULP) complaints, other than 8(a)(3) charges, in 23 percent of the campaigns, but complaints were issued in only 39 percent of the campaigns in which those ULPs were filed. Overall, including 8(a)(3)s, unions filed ULPs in 36 percent of the campaigns and complaints were issued in 53 percent of the campaigns in which ULPs were filed. Union win rates were slightly lower, but not at a statistically significant level, in campaigns in which charges were filed ( 41 percent), compared with campaigns in which no charges were filed ( 43 percent). Win rates were higher in units in which complaints were issued (53 percent), however, possibly because NLRB complaints effectively demonstrate that unions can win against the employer.

These results do not lend credence to those who would argue that existent NLRB law and practice effectively enforce union and worker rights in the organizing process. The NLRB failed to issue complaints in 47 percent of the campaigns in which charges were filed, despite repeated egregious and illegal employer behavior, including bribes, promises, threats, surveillance, and misinformation, in numerous cases. In addition, because of their extremely negative experience with the board in terms of both process and outcome, many of the organizers in the survey made a conscious decision not to bother filing unfair labor practice complaints even in cases of blatant violations.

\section{Results from the First-Contract Study}

Under our current labor law and in our current economic and political environment, employers have a number of legal and illegal means to thwart union attempts to bargain a first agreement. Not surprisingly, a majority of the employers in the sample used a broad range of legal and illegal tactics to resist the unions' efforts to reach a first agreement. Although the sample size and statistical method limited how many management tactic variables could be included in the estimated equation, the following management tactic variables were incorporated into the model: use of captive audience meetings; employer use of media, advertisements and public events; unilateral changes in wages, hours, and/or working conditions; use of an outside consultant or lawyer; concessionary initial bargaining proposals; discharges after the election; and surface bargaining. In addition, descriptive statistics were obtained for a broad range of other employer tactics relating to the first-contract campaign process.

As shown in table 5.2, employers continued captive audience meetings after the election in 21 percent of the campaigns, ran a media or public 
relations campaign in 6 percent, made unilateral changes in 37 percent, and discharged workers for union activity in 30 percent. Employers used an outside consultant or lawyer in 61 percent of the campaigns, made initial concessionary proposals in 18 percent, and engaged in surface bargaining in 37 percent. All of these actions were associated with first-contract rates 10 to 30 percent lower than in the units in which they were not used. When the influence of other contract campaign variables was controlled for, the probability of winning a first contract declined by 34 percent in units in which the employer ran a media or public relations campaign, by 13 percent in units in which unilateral changes were implemented as mandatory subjects of bargaining, by 13 percent in units in which an outside consultant was used, by 20 percent in units in which the initial proposals were concessionary, and by 24 percent in units in which, according to the union's chief negotiator, the employer engaged in surface bargaining. ${ }^{5}$

The weak effect of the captive audience meeting variable on first-contract outcome may be explained by the fact that the union has greater access to counteract the employer's message once the union has won the election. The results for the discharge variable may be explained by the fact that discharges after the election may serve more to spur the union to bargain an agreement that included reinstatement than to give the employer more leverage at the bargaining table.

Employers engaged in several additional legal and illegal tactics during the bargaining process that were not included in the multivariate analysis. As shown in table 5.2, employers engaged in a broad range of hard or bad-faith bargaining behaviors. These included refusal to respond to information requests (17 percent of the campaigns) and delay and stalling tactics, such as showing up late at negotiations, taking long caucuses, and failing to agree on dates for negotiation sessions ( 35 percent). Half the employers also bargained hard on union security language, resisting any agreement on union shop and dues checkoff clauses until the very end of bargaining, if they agreed at all.

Twenty-five percent of the employers attempted to undermine the union negotiating committee by offering bribes and promotions and by spreading rumors about individual committee members. Similarly, a third of the employers

5. The extremely strong negative effect of the employer media campaign variable is partially explained by the fact that employers are most likely to utilize the media after impasse has been reached, thus at a point when the resolution of the first contract is already in jeopardy. Newspaper advertisements, radio spots, and public forums are especially effective tools employers can use to circumvent a union and bargain directly with the employees, in order to convince them and the larger community that they will suffer permanent replacement, layoff, or plant shutdown if they fail to accept management's final offer. The effectiveness of this tactic is increased all the more by the very weak restrictions and penalties that exist under the NLRA for employer misstatements, threats, and promises included in advertisements and other public presentations. 


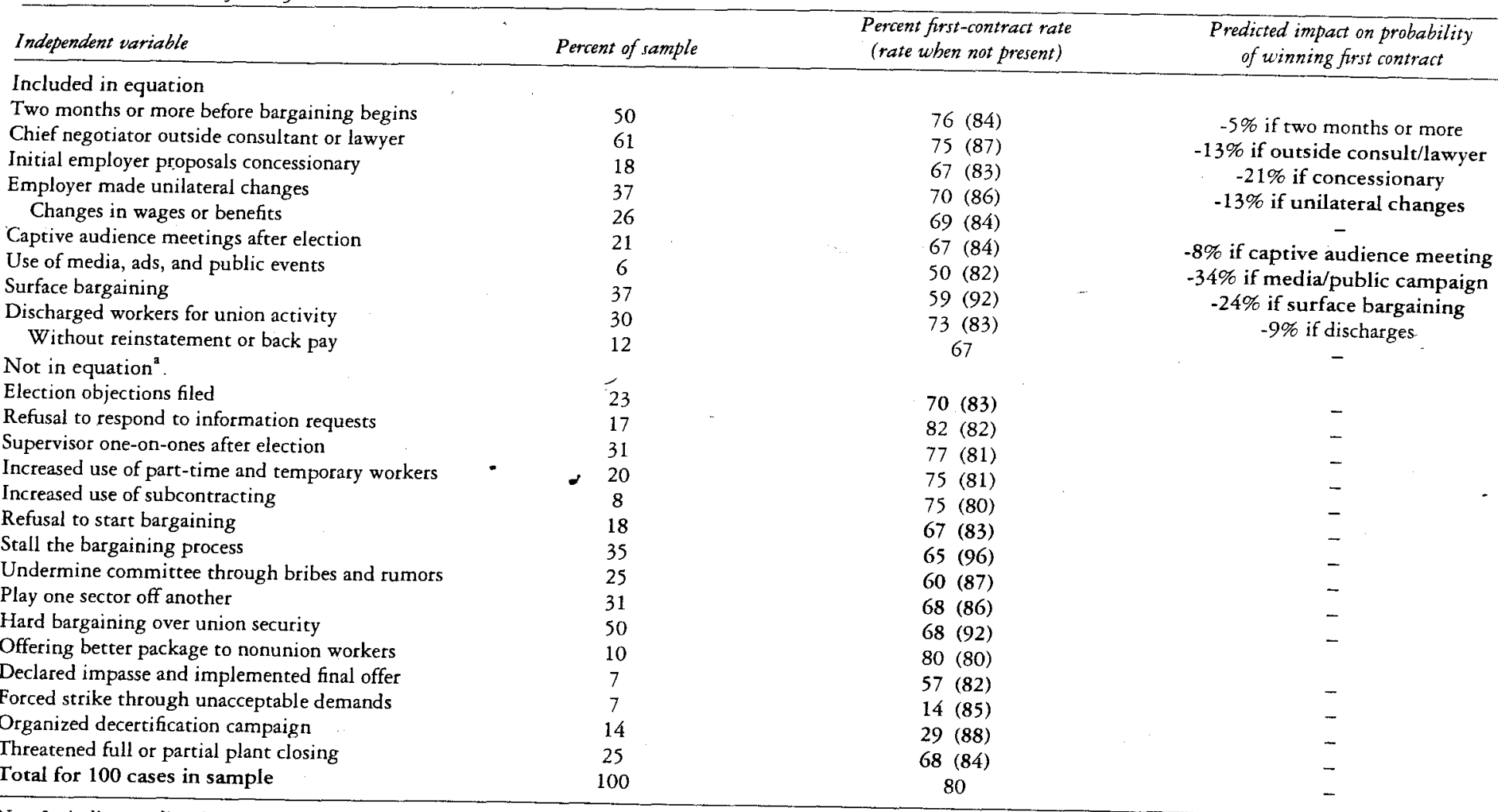

Note: Including predicted impact on petcent union vote and probability of union win for all variables included in the logit equation when controlling for the influence of the bargaining climate, company and unit characteristic, organizing campaign, negotiating process and union tactic, and characteristic variables. Statistically significant results in
predicted impact column are in bold for all variables that were included in equation.

Results in bold in percent first-contract rate column were statistically significant in a chi-squared test. 
attempted to divide the bargaining unit by playing one sector or interest group against another, either by job classification, seniority, gender, department, or race. In 10 percent of the units, the employer offered better wages to nonbargaining unit employees than they proposed at the table for the union employees.

A substantial number of the employers also engaged in more directly coercive behavior, such as threatening plant closings, forcing strikes, or organizing decertification campaigns. Employers threatened a full or partial plant closing in 25 percent of the campaigns, although they followed through on their promise to close the plant only 4 percent of the time. In 14 percent of the campaigns, the employer organized a decertificarion campaign, and unions failed to win a first contract in all but four of those fourteen campaigns. In 7 percent of the units, the employer declared an impasse and implemented the final offer, and unions won first contracts in only four of those seven units. In another 7 percent of the units, the employer forced a strike by holding to blatantly unacceptable demands. Unions were able to win a contract in only one of those strikes.

With the exception of refusing to respond to information requests and granting betrer wages to nonunion employees (which may just work as an incentive for unionized employees to fight even harder), the above-mentioned employer tactics were all associated with union win rates 25 to 50 percent lower than in units in which these tactics were not used. The negative differences in first-contract rates for all of these employer tactics were statistically significant in a chi-square test.

Twenty-three percent of the employers refused to recognize the union as the certified representative of the bargaining unit and instead filed objections with the NLRB and the courts to get the election results overturned. Although the challenges were dismissed without merit in every case, challenging the election still served effectively to delay the start of negotiations and appeared to have a negative impact on first-contract success, so that unions won only 70 percent of the campaigns in which the employer filed election objections, compared with an 83 percent first-contract rate when objections were not filed.

\section{Implications for Labor Law Reform}

The results from this study confirm that labor law reform could substantially improve union success rates in both certification elections and firstcontract campaigns. Based on the number of campaigns in which the union lost the election even though a majority or close to a majority of the unit signed cards before the petition was filed, it is clear that the union win rate in 
this sample would have been nearly double if employers had been required to grant recognition after a majority card check, as is the case in some Canadian provinces.

The number of cases in the sample in which the union lost majority support because of an adverse unit determination demonstrates the importance of restricting the ability of the board and the courts to make changes in unit determination that go well beyond the community of interest standard. This is especially true in those cases in which another entire division or workplace is added to the unit at the last minute. Workers should be able to organize with workers with whom they have a true community of interest, all at the same worksite and all in the same general work classification.

The number of campaigns in this data set in which employers engaged in clearly illegal behavior during the organizing and first-contract campaigns speaks strongly to the need for more vigorous and rapid enforcement of the law and more serious penalties for employers who violate the law. NLRB staffing levels need to be dramatically expanded at the investigation, hearing, and case-processing levels. The penalties for 8(a)(3) violations need to go beyond back pay to financial penalties significant enough to act as real deterrents. Most important, woikers and unions need the same injunctive penalties for egregious employer violations that are so readily applied for union violations.

The need for stiffer employer penalties is especially apparent in the area of bad-faith bargaining. As this study showed, numerous employers violate 8(a)(5) of the NLRA through unilateral changes, surface bargaining, and stalling tactics or simply by refusing to come to the table. Yet, under current law, the worst penalty an employer can get for these violations is an order to bargain in good faith. This points to a clear need for financial penalties or, in more egregious cases, actual settlement orders or interest arbitration.

The ever-expanding "free speech" rights of the employer, in contrast with the ever-shrinking access rights of unions, allowed many employers in this sample to mislead, misinform, and outright lie to employees about the union in captive audience meetings, leaflets, mailings, media campaigns, and public forums. Labor legislation that would better balance these rights would improve the ability of workers to make decisions regarding unionization without in any way constraining employers from expressing their opinions about unionization in a noncoercive manner. The law should be changed to include financial penalties for threats, intimidation, lies, and distortion, whether expressed in written communications or in captive audience meetings and supervisor one-on-ones. Equally important, the law needs to be amended to offer frequent and full opportunities for union representatives to have equal time and equal access to counteract the "captive" nature of employer communication. 
The campaigns in the sample in which the employer was able to defeat the union through the use of permanent replacement workers underscore the importance of labor law reform to eliminate the employers' right to hire permanent replacements in economic strikes and temporary replacements during lockouts. The cases in which employers actively organized antiunion committees, bribed or undermined organizing and bargaining committee members, used participation programs to thwart organizing drives, or initiated decertification campaigns give strong support to those in the labor movement who argue for strengthening rather than diluting the penalties and enforcement of $8(\mathrm{a})(2)$ violations.

The last and perhaps most critical area of labor law reform is suggested by the more than 25 percent of the campaigns in which the employer threatened a full or partial shutdown of the plant and the 8 percent of the campaigns in which unions lost representation because of plant closings. These campaigns demonstrate the critical need for some restrictions and/or penalties for employers that shut down operations or contract out work to avoid unionization. For, under current labor law, employers can take these actions without fear of penalty and only in the most exceptional circumstances can union internal and external pressure campaigns force a setclement.

\section{Conclusions}

These results make it clear that under current labor law organizing is an extremely difficult and risky venture for private-sector workers. The results also demonstrate that labor law reforms that would expand union and worker rights while restricting and punishing illegal employer behavior could significantly reverse the downward trend in organizing. Given that the impact of many of the individual employer tactics on percentage union vote, election outcome, and first-contract outcome ranged from 10 to 20 percent, these reforms in combination could bring union election win rates above 80 percent and first-contract win rates close to 100 percent. These labor law reforms could also dramatically increase the number of union election campaigns by greatly reducing employers' ability to crush union organizing efforts before they get to an election or even a petition.

A word of caution is in order, however. Both the larger certification and first-contract studies made it clear that union behavior also plays an extremely critical role in determining certification election outcomes. As many Canadian organizers have found, labor law alone does not organize workers. There were cases in this sample, albeit few in number, in which, despite a complete lack of employer opposition, the union still was unable to win an election. At the same time, although overall union win rates hover below 50 percent and first-contract rates run below 75 percent, some unions and some organizers 
are winning elections and first contracts despite labor law, despite an adverse political and economic climate, and despite aggressive employer antiunion campaigns. These unions are able to win because they are using creative, aggressive rank-and-file intensive organizing and first-contract strategies. In fact, as the findings from my broader certification election study make clear, union tactics as a group play a greater role in determining election outcome than any other group of variables, including employer behavior and NLRB practices (Bronfenbrenner 1993:301).

As union density in the private sector plunges toward 10 percent, it would be suicidal for the labor movement to depend on labor law reform for its resurrection. In fact, the only way unions will achieve significant labor law reform is to go out and organize millions of American workers, who in turn can lobby Congress and the president for reform.

Unfortunately, time is running out. If the labor movement is going to reverse the downward spiral before it is too late, it needs immediately to reevaluate the way it has organized in the past and develop a comprehensive plan to revamp its organizing structure and strategy. Only then can labor law reform be achieved and only then can we rebuild an active and vital labor movement, which is so critical to the very existence of a democratic and humanist society. 